UDC $130.2+008$

\title{
SEMANTIC FIELD OF CONCEPT "TRADITION" IN PHILOSOPHICAL LINKS OF OSTROG SCRIBES
}

S. M. Gumenyuk, PhD of Philosophical Sciences, Associate Professor, National University of Water Management and Natural Resources.

E-mail: s.m.humeniuk@nuwm.edu.ua

The basis of the study is the problem of defining the concept of "tradition". With his help, the author analyzes the phenomenon of Ostrog book publishing in the second half of the sixteenth and early seventeenth centuries, defending the idea that the development of Ukrainian culture takes place in line with traditionalism.

Ostrog traditionalism is a current that protects Orthodoxy as the Catholic faith, defines modern through the past and represents, first of all, the spiritual efforts of the Ukrainian people in preserving their own cultural foundations, which are identical with the preservation of their own cultural identity.

The author comes to the conclusion that the term "tradition" in the context of the study exploded in the category "Ostrog Orthodox Traditionalism" as a remarkable spiritual phenomenon, which requires further interdisciplinary research.

Keywords: tradition, Ostrog book publishing, traditionalism, orthodoxy.

https://doi.org/10.21272/Ftrk.2018.10(4)-1

The relevance of research. The problem of terminology and term creation in the contemporary Ukrainian philosophical discourse is dominated, in particular the announcement of the "Spirit and Letter" publication, the European Dictionary of Philosophies focuses on the attention of academics to the lexicon of immaturity, justifying this project as a challenge to the traditional understanding of philosophy as such. The edition of the Dictionary notes that for Ukrainian translators and co-authors of the project "there are still no tests of such a level of depth and complexity" [1, p.8-9]. Consequently, modern philosophical thought considers the task of terminology to be the first priority.

First of all, we will be interested in the term "tradition", since the definition of this term in the context of the philosophical thought of Ukraine in the second half of the sixteenth and early seventeenth centuries is extremely broad and ambiguous.

The purpose of the study is to find out the definitions of the concepts of "tradition" and "traditionalism", as well as their cultural and philosophical explication in the context of studying the phenomenon of Ostrog book publishing.

Many researchers, including the names of V. Horskyi, A. Dondiuk, Y. Stratii, S. Yosypenko, emphasize the special role of tradition in the formation of their own image of the cultural world. It is impossible not to take into account the opinion of I. Liubashchenko that in the fifteenth-seventeenth centuries the Renaissance did not find adequate in its Western European model of implementation in Ukraine. Ukrainian contemporary humanism, which the researcher calls Byzantine humanism, proves that it

(C) Gumenyuk S. M., 2018 
was "at ecclesiastical, moderate, full of deep mysticism, and rejected radicalism and secularization potential of early reformation ideology" [2, c.53]. These thoughts become clear in the context of a profound reflexive analysis of the contemporary worldview, the result of which was the researcher's conclusion that the reformist-humanist ideas in the analyzed period led to "humiliation of culture" and to "desacralization of consciousness". Tradition also became the key to preserving the sacred image of culture.

Consequently, the most important for the context of our study is the statement about the existence in Ostrog culture and education center of the Orthodox direction as well as the statement that according to the extreme conditions of violent, aggressive "externalization of inoculultural influences", reformational and humanistic ideas were developed by Ostrog book publishing "within the limits of the characteristic Ukrainian people type of spirituality" [3, c.145], which allows us to talk about the essential reasons to call the traditional moral and religious principles of creativity of a number of representatives of the polemical camp.

At the very least, those who were guided by the orthodox doctrine as the most important benchmark for their creative ideas and in the process of inocultural reformational and humanistic (in their western interpretation) influences did not deny this semantic doctrine, can be called traditionalists.

So, we need to give an expanded interpretation of this key term for our study. Consequently, the term traditionalism does not claim exclusivity. There have already been attempts to isolate the traditional course in the cultural space of Ukrainian Pre-Renaissance and Renaissance, but in previous intelligence, it was called "conservative". However, in the context of our study, which is based not on the political direction but on the search for a spiritual moral and religious platform in the work of Ostrog cultural and educational figures, the term "traditionalism" would be more appropriate in our opinion, since conservatism is a flow in the political movement and this term appears to be just as political. It is important for us not to omit other dimensions and properly describe the phenomena that represent the cultural movement, its features, and specifics, because the political component, although important, is not decisive.

Consequently, the notion of traditionalism is also, for this reason, the most adequate term, in our opinion, to cover the realities of the spiritual and cultural life of this period.

In the worldview, the notion of "tradition" is studied by many philosophers (E. Shils, Y. Pelikan, M. Konhar, etc.). In modern scientific literature, the most authoritative in this regard is the work of Paul Vallier "Tradition" [4, p.646].

Let's take advantage of the comments of the author. The etymology of this term comes from the Latin noun tradere ("transmission"). Traditio exactly corresponds to the Greek paradosis, which also comes from the verb, which means "transmit" (paradidomi). Traditio and paradidomi can be used both literally and figuratively. Traditio and paradidomi for Christian theologians usually mean in this sense the totality of teachings that the Church preserved and transmitted as "Catholic faith". However, in today's religious studies, it is necessary to use a broader and differentiated notion of tradition.

Paul Vallier notes that the concept of tradition is used in all areas of culture - science, education, art, literature, politics, law and religion.

It is interesting to note that in the dictionary, which Boris Hrinchenko arranged, there is no word "tradition" [5, p.279]. Obviously, this term was not of particular interest to the editorial office of the magazine "Kyiv Ancient", which collected material for the publication of the Ukrainian language dictionary at the beginning of the twentieth century (the dictionary was published in 1909). How and why he got lost, I think that this question remains open and requires a painstaking work of researchers of the Ukrainian language. Instead, in the dictionary of the Russian language, the term "tradition" is interpreted, firstly, as "Historically developed and handed down from generation to generation customs, norms of behavior, attitudes, tastes, etc.", secondly as "Established order, unwritten law in behavior, in everyday life; custom, wont", thirdly as "The usual, fixed form of smth.". Let's also pay attention to the fact that this dictionary in the interpretation of the term 
"traditionalism", emphasizes our attention to its connection with the sphere of conservatism. Philologists interpret it as a book-like term, as "Loyalty, following the traditions (usually obsolete)" [6, p. 396].

The new interpretive dictionary of the Ukrainian language, unfortunately, does not offer us any interpretation of the notion of "traditionalism", and the notion "tradition" offers almost a literal translation of a vocabulary article from a previous source, namely, "Experience, customs, views, tastes, norms of behavior, etc., formed historically and passed from generation to generation"; "The usual accepted norm, behavior, standing opinions, persuasion of someone; custom, common, unwritten law" [7, p.558].

Modern culturological science at this stage of development is used for the collection of terminologists, among which Volodymyr Antrofiichuk takes a prominent place. In particular, the terminology dictionary of the series "Culturology" concluded by this author has been reissued many times and is in high demand among students. V. Antrofiichuk emphasizes that the term "tradition" is widely used in culturology and refers to elements of a social or cultural heritage that are passed from generation to generation and are preserved by certain social groups for a long time [8, p.139].

For completeness of the study, we also became acquainted with the full Church Slavonic Dictionary [9], because our study appeals to religious studies, but, unfortunately, neither the notion of "tradition" nor the notion of "traditionalism" in this dictionary, which interprets Church Slavs was not found.

However, modern philosophers often use these concepts in their intelligence. In particular, the Ukrainian Philosopher M. Bulatov outlines the tradition as a concept that determines the various forms of influence of the past on the present and the future. Essential for our study is the scholar's assertion that the role of tradition is decisive in the formation of ideological values and beliefs [10, p.646].

In view of the foregoing, we conclude that the term is polysemantic. Construed in this sense, the concept of "tradition" naturally fits in the context of our search and forms the basis of its key concept - traditionalism, as the currents of the cultural and educational religious movement that is ontologically inherent in the Ukrainian reality of the PreRenaissance and Renaissance epochs.

Consequently, Ostrog traditionalism is a current that protects Orthodoxy as the Catholic faith, defines modern through the past and represents, first of all, the spiritual efforts of the Ukrainian people in preserving their own cultural foundations, which are identical with the preservation of their own cultural identity. Under the Ostrog traditionalism, we understand that part of the Ostrog book publishing, which professed the Orthodox spiritual tradition, having its essence as the core of culture, was marked by the active influence of Byzantium and Greece, and, despite all the pressure, proved its allegiance to its ideas. Immediately, we should note that the Ostrozkyi cultural and educational center was not a narrow local phenomenon, but rather large, therefore the name "Ostrog" is rather conditional, since the notion of traditional Ukrainian spirituality is connected with Ostrog as the core of the cultural moral and religious life of Ukrainians at the end of the sixteenth and at the beginning of the seventeenth century, other regions of that time, which, taken together, create a world-view monolith of the spiritual world of Orthodoxy in Ukraine. Because of that time, Ostrog can be distinguished neither Zahorov, nor Dubna, nor Dermany, nor Pochaiev, nor Maniavskyi hermitage, created on the model of the Athos monasteries. In our opinion, the Ostrog culture and education center is a rather spiritual than a territorial phenomenon, because its teachers, advisers, scholars, and graduates sowed the spiritual seeds of the traditional moral and religious thought not so much on the territory of the Polish-Lithuanian state as in the souls and hearts of their compatriots.

In this regard, we pay attention to the names of Vasyl Surazkyi (Maliushitskyi), Iov Kniahynytskyi, Herasym Smotrytskyi, Damian Nalyvaiko, Kliryk Ostrozkyi, Tymofii Mykhailovych, and the most famous Ukrainian polemicist Joann Vyshenskyi, who lived until the 70s of the sixteenth century in Ostrog. The figure of Vitalii from Dubna is not closely investigated with them, close to the outlook, as well as the region of residence. 
However, the list of these names does not exhaust the completeness of the phenomenon under study, since the activities of Ostrog traditionalists cannot be reduced to literary polemics. Traditionalism is a much wider phenomenon and the literary framework is too narrow for him. Spiritual horizons of the then Ukraine are not closed by educational propaganda and literary activities.

Representatives of spiritual searches in the area of the Orthodox tradition, who had a direct or indirect relation to the Ostrog culture and education center, also became Iov Pochaivskyi, who for a long time (about 20 years) communicated with Prince VasylKonstantin Ostrozkyi and was his spiritual mentor; Isakii Sviatohorets (Boryskovych) is the abbot of the Dermansk monastery, who had a significant spiritual experience from the Holy Mountain and many years of communion with the Orthodox patriarch Meletii Pihas; hieromonk Cyprian - famous translator from Greek to the Church Slavonic language of the works of Makarii Yehypetskyi, a member of the Anti-Catholic Brest Cathedral and coordinator of meetings with the Eastern patriarchs; an active defender of Orthodoxy Iov Boretskyi was an Orthodox Metropolitan who collaborated with the Ostrog College, and, according to the assumption, I. Mytska was her graduate and author of the work "Warning" ; the hieromonk Afanasii, the founder of the Mezhyhirskyi Monastery, who was brought up under Prince Vasyl Ostrozkyi's "In good book punishment", judging by the Gostinsky Chronicle in 1600, returned from Athon, and from the records of the Mezhyhirskyi Monastery - the heir to the holy-Athos spiritual traditions, Isaiia Balaban - archimandrite of Unew, who was engaged in editorial work, associate with Iov Kniahynytskyi - abbot Herasym Uhornytskyi; Lonhyn Karpovych- a prominent anti-Catholic figure, the author of the forums to the vilnuse edition, the Archimandrite of the Holy Trinity Monastery, who maintained connections with the Ostrog and Zabludovskyi cultural centers, in particular, for the help in publishing the "Trainos", he spent two years in prison; hieromonk Flavian Kasianovych, editor and translator of Greek, Latin and Polish languages, hieromonk Ilarion, expelled by the Polish king from the state for refusing to submit to the Uniate Archimandrite Ipatii Potii; Tymofii Mykhailovych (Annych) - deacon, and later "priest Polotskyi" - the author of the alphabetical index of the New Testament called "The book assembles the necessary things ...", which was printed by I. Fedorov.

Conclusions. Hence, the Ostrog traditionalists are representatives of the Ostrog book publishing, as well as cultural figures who collaborated with the Ostrozkyi cultural and educational alphabet, who took an uncompromising stand on the protection of the "old faith", that is, Orthodoxy, Church Slavonic language, the old Julian calendar, and expressed a sharp protest against the introduction of the union on the Ukrainian lands at the turn of the sixteenth and early seventeenth centuries. The notion of Ostrog traditionalism is more fully outlined against the backdrop of Renaissance-humanist tendencies unfolding in Ukraine in connection with the expansion of Catholicism and counter-reform.

These effects are explored more fully, and therefore may give a false picture of their dominant role in shaping the moral and religious principles then reality. Ostrozkyi traditionalism as a remarkable spiritual phenomenon deserves to be the subject of a separate philosophical study. His need is urgent in connection with the definition of Ukraine's own worldview status in contemporary European territories.

Consequently, the term "tradition" in the context of our study is exploded into the category "Ostrozkyi Orthodox traditionalism" as a remarkable spiritual phenomenon, which requires further interdisciplinary research.

\section{СЕМАНТИЧНЕ ПОЛЕ ПОНЯТТЯ «ТРАДИЦІЯ У ФІЛОСОФСЬКИХ ПОШУКАХ} ОСТРОЗЬКИХ КНИЖНИКІВ

С. М. Гуменюк, канд. філософ. наук, доиент,

Начіональний університет водного господарства та природокористування

E-mails.m.humeniuk@nuwm.edu.ua 
Основою дослідження є проблема дефініції поняття “традиція” та його культурно-філософська експлікація у контексті розвитку філософської думки України другої половини XVI-поч. XVII cm.

Авторказвертає увагу на те, шо термін «традииія» трансформується у категорію «острозькии православний традиціоналізм», який утворює власне семантичне поле у культурі аналізованого періоду. Воно актуалізується у філософській спадщині острозьких традиціоналістів - представників острозького книжництва (Василь Суразький (Малюшицький), Іоанн Вишенський, Іов Княгиницький, Герасим Смотрицький, Даміан Наливайко, Клірик Острозький, Тимофій Михайлович, Віталій з Дубна та ін.), а також культурних діячів, котрі співпрачювали з Острозьким культурно-освітнім осередком $i$ зайняли безкомпромісну позицію щцодо захисту православ'я, иерковнослов'янської мови, старого юліанського календаря та висловили різкий протест проти запровадження унії на українських землях на рубежі ХVI-го - XVII-го століть.

Феномен українського традиціоналізму у контексті острозького книжництва донині залишається відкритою темою для дослідників, які прагнуть відиукати у ньому потенційні зародки формування національного образу культури в ї̈ автентичному вияві та ствердити ї̈ самобутній духовний лик, грунтований на православній традииії. I на сьогодні беззаперечним залишається факт культуротворчоі невиснажуваності філософії острозьких традичіоналістів, які гідно витримали полеміку з Заходом. ствердивии иіннісний вимір власних духовних надбань.

Авторка дослідження приходить до висновку про те, щчо звернення до філософської площини вітчизняної духовної культури задає нову векторність національного самопошуку.

Ключові слова: традиція, острозьке книжництво, традииіоналізм, православ'я.

\section{СЕМАНТИЧЕСКОЕ ПОЛЕ ПОНЯТИЯ «ТРАДИЦИЯ» В ФИЛОСОФСКИХ ПОИСКАХ ОСТРОЖСКИХ КНИЖНИКОВ}

С. Н. Гуменюк, канд.философ. наук, дочент,

Национальный университет водного хозяйства и природоведения

E-mails.m.humeniuk@nuwm.edu.ua

Основой исследования является проблема дефиниции понятия “традиция”. С его помощью автор анализирует феномен острожских книжников второй половины XVI - поч. XVII ст., защищая мысль о том, что развитие украинской культуры происходит в русле традиционализма.

Острожский традиционализм определяется как течение, которое защищало православие как кафолическую веру, определяло современное через прошлое и представляло в первую очередь духовнье усилия украинского народа в сохранении собственных культурных оснований, тождественных сохранению собственной культурной идентичности.

Автор приходит к выводу о том, что термин «традиция» в контексте исследования експлицируется в категорию «Острозький православный традиционализм» как неординарное духовное явление, которое нуждается в последующих межотраслевых исследованиях.

Ключевые слова: традиция, острожские книжники, традиционализм, православие.

\section{REFERENCES}

1. Philosophical Encyclopedic Dictionary: [contains 1700 pp. / redcall.: Shynkaruk, V.I. (head), etc.]; NAS of Ukraine, Institute of Philosophy named after G.S. Skovoroda. Kyiv: Abrys, 2002. 742 p.

2. Secularization of spiritual life in Ukraine in the era of humanism and the Reformation. Academy of Sciences of the USSR, In.-t. Soc. Sciences; [Rep. Ed. A. Ye. Hryniv]. Kyiv: Science. opinion, 1991. 280 p.

3. Nichyk V. M., Lytvynov V. D., Stratii Y. M. Humanistic and Reformation Ideas in Ukraine XVI - early XVII centuries. Kyiv: Science. opinion, 1990. 384 p.

4. Philosophical Encyclopedic Dictionary. NAS of Ukraine, Institute of Philosophy named after G.S. Skovoroda. Kyiv: Abrys, 2002. 742 p.

5. Dictionary of the Ukrainian language. Arranged with the additional material of Borys Hrinchenko: In four volumes. T.4. R-I / NAS of Ukraine. Institute of the Ukrainian language. Kyiv: Science. Opinion, 1997. 616 p.

6. Dictionary of the Russian language in four volumes. Vol. IV / USSR Academy of Sciences, Institute of Russian Studies. - 3rd ed. stereotype. Moscow: Russian language, 1985-1988. Vol. 4. S.-Y. 1988. 800 p.

7. New Explanatory Dictionary of the Ukrainian language in four volumes. Rob. -Y. Kyiv: Ed. "Akonit", 1999. Vol.4. 944p.

8. Culturology. Terminological dictionary. - 3rd edition. Chernivtsi: Books XXI, 2009. 160 p.

9. Complete Church Slavic Dictionary. Archpriest G. Diachenko. Reprinted reproduction of 1900. Mozhaisk, LLC Ed. Ancestral Home, 2004. 1120p.

10. Philosophical Encyclopedic Dictionary. NAS of Ukraine, Institute of Philosophy named after G.S. Skovoroda. Kyiv: Abrys, 2002. 742 p.

СПИСОК ВИКОРИСТАНИХ ДЖЕРЕЛ

1. Філософський енциклопедичний словник : [містить 1700 ст. / редкол.: Шинкарук, В. І. (голова) та ін.] ; НАН України, Ін-т філософії ім. Г. С. Сковороди. - Київ: Абрис, 2002. - 742 с. 
2. Секуляризація духовного життя на Україні в епоху гуманізму і Реформації : зб. наук. пр. / АН УРСР, Ін.-т. сусп. наук ; [відп. ред. А. С. Гринів]. - Київ : Наук. думка, 1991. - 280 с.

3. Нічик В. М. Гуманістичні і реформаційні ідеї на Україні XVI - початку XVII ст. / Нічик В. М., Литвинов В. Д., Стратій Я. М. - Київ : Наук. думка, 1990. -384 с.

4. Філософський енциклопедичний словник : [містить 1700 ст. / редкол.: Шинкарук, В. І. (голова) та ін.] ; НАН України, Ін-т філософії ім. Г. С. Сковороди. - К. : Абрис, 2002. - 742 с.

5. Словарь української мови. Упорядкував з додатком власного матеріалу Борис Грінченко: В чотирьох томах.Т.4.Р-Я/НАН України. Ін-т української мови. - К.: Наук. Думка, 1997. - 616 с.

6. Словарь русского языка в четырех томах. Т.IV/ АН СССР, Ин-т рус. яз.; Под ред. А. П. Евгеньевой. 3-изд. стереотип. - М.: русский язык,1985-1988. Т. 4. С.-Я. 1988. 800с.

7. Новий тлумачний словник української мови у чотирьох томах / ред. Л. І. Андрієвський. Т.4 / Роб.-Я. К.: Аконіт, 1999 р. - 944c.

8. Культурологія. Термінологічний словник.: Навчальний посібник. - 3-є видання. Чернівці:Книги ХХІ, 2009. $-160 \mathrm{c}$

9. Полный церковно-славянский словарь. Протоиерей Г.Дьяченко. Репринтное воспроизведение 1900г. г.Можайск, ООО Изд.-во «Отчий дом», 2004. 1120с

10. Філософський енциклопедичний словник : [містить 1700 ст. / редкол.: Шинкарук, В. І. (голова) та ін.] НАН України, Ін-т філософії ім. Г. С. Сковороди. - К. : Абрис, 2002. - 742 с.

Received: 03 Desember, 2018 